WORKING PAPERS No. 53

\title{
EXCHANGE RATE REGIMES \\ AND INFLATION AND OUTPUT \\ IN SUB-SAHARAN COUNTRIES
}

by

Marc Klau

March 1998

BANK FOR INTERNATIONAL SETTLEMENTS

Monetary and Economic Department

BASLE 
BIS Working Papers are written by members of the Monetary and Economic Department of the Bank for International Settlements, and from time to time by other economists, and are published by the Bank. The papers are on subjects of topical interest and are technical in character. The views expressed in them are those of their authors and not necessarily the views of the BIS.

(C) Bank for International Settlements 1998

CH-4002 Basle, Switzerland

Also available on the BIS World Wide Web site (http://www.bis.org).

All rights reserved. Brief excerpts may be reproduced or translated provided the source is stated. 


\title{
EXCHANGE RATE REGIMES \\ AND INFLATION AND OUTPUT \\ IN SUB-SAHARAN COUNTRIES
}

by

Marc Klau *

March 1998

\begin{abstract}
The paper studies the role of real exchange rates and exchange rate policies in explaining differences in the economic performance in the CFA franc countries, with their fixed exchange rate regime, and another group of countries in SubSaharan Africa with more flexible arrangements. Policy-makers in inflation-prone countries are faced with a permanent dilemma: should policy priority be given to containing inflation or to maintaining competitiveness through currency depreciation. This policy conflict tends to be aggravated by the fact that in both country groups devaluations seem to have a positive impact on economic activity, throwing doubt on previous work on possible contractionary effects of devaluations. Even so, the question as to whether the pegging of an exchange rate is advantageous, when taking account of both output and inflation effects, remains open, as it partly depends on the supply shocks to which the countries are exposed.
\end{abstract}

I would especially like to thank Palle Andersen for very useful advice and encouragement. Thanks are also due to Stephan Arthur, Joseph Bisignano, Stefan Gerlach, Robert McCauley, Ib Madsen and Frank Smets. 


\section{Contents}

Introduction

1. Comparative economic developments in Sub-Saharan African countries .................... 3

$1.1 \quad$ Growth and inflation performance ………….................................................... 3

$1.2 \quad$ Fiscal indicators ........................................................................................... 5

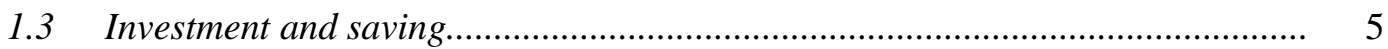

$1.4 \quad$ External sector developments ...................................................................... 7

2. Recent research on inflation and output in developing countries ............................... 9

3. Analytical framework and estimation approach ................................................ 11

3.1 The inflation equation .................................................................................. 11

3.2 The output equation .................................................................................... 13

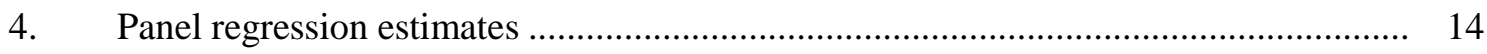

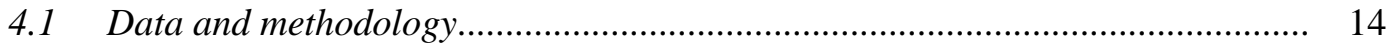

4.2 Linkages between consumer price inflation and the exchange rate ................... 14

4.3 Linkages between output growth and the exchange rate ................................... 18

Conclusion

Appendix 1

References 


\section{Introduction}

The economic performance of Sub-Saharan Africa over the past two decades has been rather poor compared with other developing regions. Real per capita income has risen little and has even declined in some countries, while inflation has proved difficult to control. A closer examination of individual country results reveals, however, significant variations over time and between different countries. This paper focuses on the role that real exchange movements and related exchange rate policies might have played in explaining such variations and differences.

To do so, two groups of countries are considered: the CFA (Communauté Financière Africaine) franc countries, which maintained a fixed exchange rate vis-à-vis the French franc between 1948 and early 1994, when their currency was devalued by 50\% against the French franc; and another group of Sub-Saharan countries which have frequently adjusted their exchange rates in order to preserve or strengthen their competitiveness. The countries in both groups present similarities in terms of economic structure and history. Being highly dependent on one or two primary commodity exports, they have been vulnerable to adverse developments in world market prices and have been exposed to similar external shocks. However, because of their different exchange rate regimes, they have reacted in different ways to these supply shocks. Thus, the two selected country groups would seem to provide suitable samples for examining the effects of exchange rate changes and real exchange rate levels on growth and inflation.

Indeed, as illustrated in the upper panels of Chart 1, the different experiences of these two country groups point to the possibility of a relationship between the rate of inflation and the level of real exchange rates. In addition, the lower panels suggest that the fear of a contractionary effect of exchange rate devaluations is unfounded for Sub-Saharan Africa. If that preliminary interpretation is confirmed by statistical testing, it could imply for the CFA franc countries that, depending on the weights assigned to growth and inflation in the general welfare function, the inflation benefits of foregoing the use of the exchange rate instrument may not have fully compensated for the losses associated with a prolonged period of contraction. On the other hand, the advantage that CFA franc countries gained in terms of having currencies that were fully convertible among each other and into the French franc should be kept in mind.

The empirical work which has been undertaken to explore possible links between exchange rates and inflation rates and output is based on the analytical framework developed by Kamin (1997), which provides evidence on the existence of an empirical relationship between the rate of inflation and the level of the real exchange rate in selected Latin American and Asian countries and advanced industrialised economies. It is also based on a follow-up study by the same author in collaboration with the author of this paper, which measures the effects of real exchange rate changes on output for the same group of countries. ${ }^{1}$ As the results of both papers led to some rather firm

\footnotetext{
1 Kamin and Klau (1997).
} 
conclusions and policy implications, it is of interest to see whether they also hold for Sub-Saharan African countries.

\section{Chart 1}

\section{Inflation, real GDP and real bilateral exchange rates}
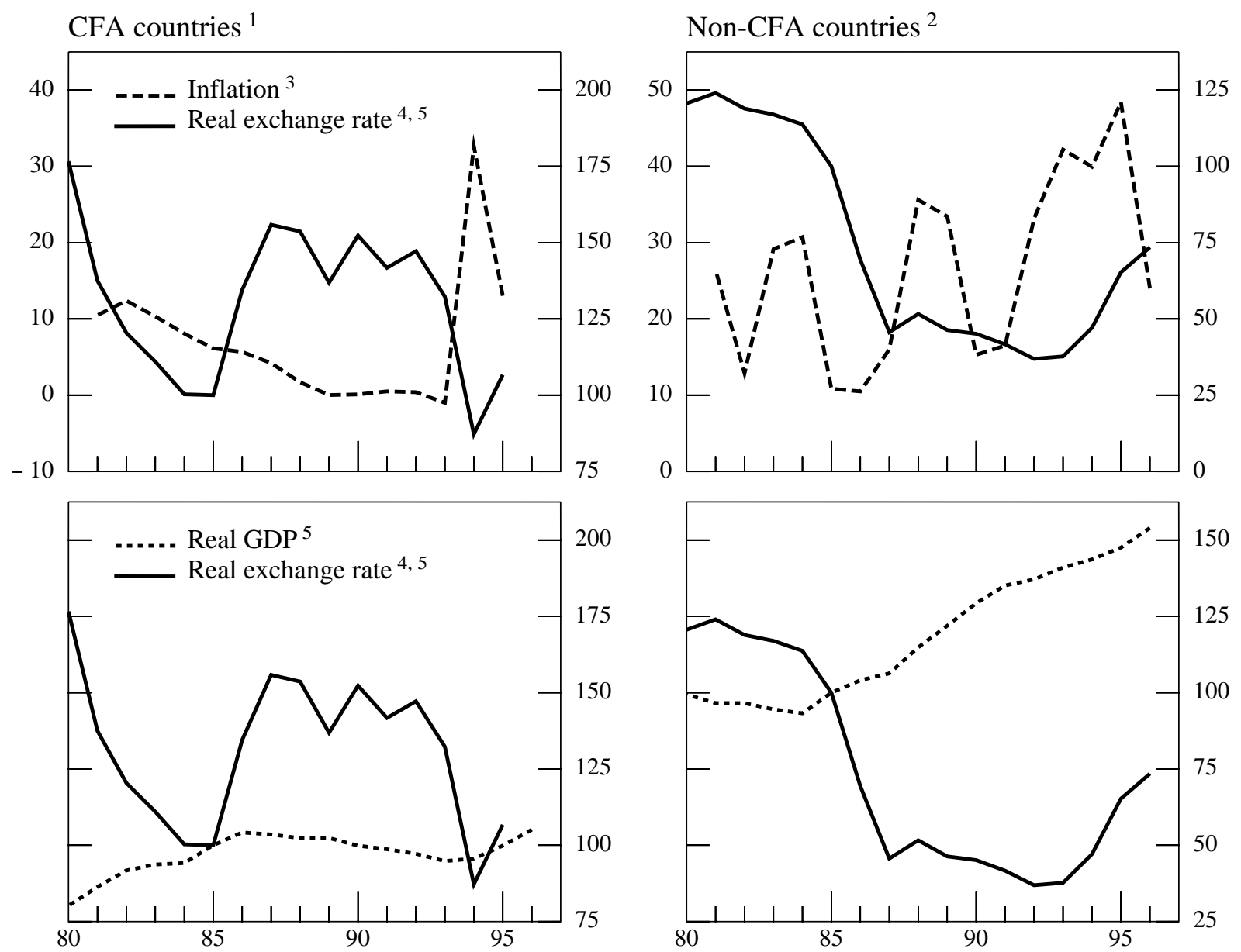

Note: The countries listed below are aggregated using 1990 GDP and PPP exchange rates.

${ }^{1}$ Burkina Faso, Cameroon, the Central African Republic, the Republic of Congo, Côte d'Ivoire, Gabon, Niger, Senegal and Togo. ${ }^{2}$ Botswana, the Gambia, Ghana, Kenya, Malawi, Mauritius, Nigeria, Sierra Leone, Tanzania and Zimbabwe.

${ }^{3}$ Annual percentage changes in consumer prices; left-hand scales. $\quad{ }^{4}$ Vis-à-vis the US dollar; an increase indicates an appreciation of the domestic currencies. ${ }^{5} 1985=100$; right-hand scales.

Before presenting the analytical framework in Section 3 and discussing the panel regression estimates in Section 4, some background material on aggregate macroeconomic performance and policy indicators for the countries belonging to the two groups considered here is provided in Section 1. This brief overview is intended to highlight differences in the development of some key economic variables. The results of relevant previous research on inflation and output in developing countries are reviewed in Section 2, in order to establish a background against which the findings of this paper, summarised in the concluding section, can be evaluated. 


\section{Comparative economic developments in Sub-Saharan African countries}

The dividing line between the two groups of countries covered in the present study is the foreign exchange rate regime adopted. The main characteristic of the CFA franc zone is clearly the common currency, the CFA franc, which is freely convertible into French francs at a fixed rate, thus providing an anchor for economic and financial policies (see Appendix 1 for more details). ${ }^{2}$ By contrast, the other Sub-Saharan countries, called for present purposes "non-CFA" countries, have their own national currencies, whose exchange rates have frequently been adjusted in response to external shocks or other undesirable changes in relative competitiveness. ${ }^{3}$

\subsection{Growth and inflation performance}

During the past two decades average economic growth in the two African regions has been among the weakest in the developing world. With continued rapid population growth, average per capita income has stagnated at a very low level. This has been in sharp contrast to developments elsewhere, most notably in Asia (see Table 1).

The output performance has, however, been very uneven both over time and across countries. Total output of the CFA franc countries expanded relatively rapidly in the early 1980s but tended to shrink thereafter. In fact, it was only with the drastic devaluation in January 1994 that a partial recovery of output was triggered. The profile of growth has been quite different in the non-CFA zone, which, since the mid-1980s, has experienced a sustained period of positive real per capita income growth.

Inflation in the non-CFA countries has, however, been persistently higher than in the CFA area. Various stabilisation programmes have had no lasting effect in containing inflation. Indeed, consumer price inflation rose to more than $40 \%$ in 1994-95, exceeding that of the sharply devaluing CFA franc countries by a large margin. The main factor contributing to the comparatively low inflation in the CFA area has, no doubt, been the nominal anchor provided by the CFA franc's fixed parity vis-à-vis the French franc. Following the absorption of the 1979 oil price shock and its repercussions on other international prices, the 1980s and the early 1990s were characterised by a steady deceleration of inflation, helped by a sustained contraction in monetary expansion. The subsequent surge of inflation was a consequence of the 50\% devaluation of the CFA franc against the French franc.

2 The CFA franc countries included in this study are Burkina Faso, Cameroon, the Central African Republic, Chad, the Republic of Congo, Côte d'Ivoire, Gabon, Mali, Niger, Senegal and Togo. Benin, Equatorial Guinea and the Islamic Federal Republic of the Comoros are also members of the CFA franc zone but were not included here owing to insufficient data.

3 The "non-CFA" countries are Botswana, the Gambia, Ghana, Kenya, Malawi, Mauritius, Nigeria, Sierra Leone, Tanzania, Uganda and Zimbabwe. In some cases Nigeria was excluded as GDP dominates the "non-CFA" group and is highly dependent on deveploments in the oil market. 
Table 1

Selected economic indicators in different regions of the developing world ${ }^{1}$

Average annual percentage changes ${ }^{2}$

\begin{tabular}{|c|c|c|c|}
\hline & 1981-85 & 1986-93 & 1994-95 \\
\hline \multicolumn{4}{|l|}{ CFA countries } \\
\hline Real GDP & 4.3 & -0.4 & 2.8 \\
\hline Real GDP per capita & 0.6 & -3.2 & -0.8 \\
\hline Consumer prices & $9.5^{3}$ & $1.3^{4}$ & 22.3 \\
\hline M2 & 15.1 & -1.6 & 19.9 \\
\hline Real effective exchange rate & $137^{3}$ & $134^{4}$ & 87 \\
\hline Terms of trade & 89 & 95 & 69 \\
\hline \multicolumn{4}{|l|}{ Non-CFA countries } \\
\hline Real GDP & 0.4 & 4.4 & 3.0 \\
\hline Real GDP per capita & -2.5 & 2.1 & -0.2 \\
\hline Consumer prices & $21.7^{5}$ & 28.0 & 41.4 \\
\hline M2 & 18.1 & 32.3 & 27.7 \\
\hline Real effective exchange rate & $124^{5}$ & 72 & 47 \\
\hline Terms of trade & 95 & 73 & 61 \\
\hline \multicolumn{4}{|l|}{ Latin America } \\
\hline Real GDP & 1.1 & 2.7 & 2.7 \\
\hline Real GDP per capita & -1.0 & 0.8 & 1.6 \\
\hline Consumer prices & 94.2 & 206.6 & 126.9 \\
\hline M2 & $107.2^{6}$ & 219.1 & 99.1 \\
\hline Real effective exchange rate & 147 & 87 & 113 \\
\hline Terms of trade & 110 & 98 & 86 \\
\hline \multicolumn{4}{|l|}{ Asia } \\
\hline Real GDP & 5.5 & 7.4 & 7.7 \\
\hline Real GDP per capita & 3.4 & 5.8 & 6.1 \\
\hline Consumer prices & 8.0 & 5.9 & 6.4 \\
\hline M2 & $19.6^{7}$ & $21.1^{8}$ & 18.1 \\
\hline Real effective exchange rate & 114 & 83 & 76 \\
\hline Terms of trade & 106 & 93 & 91 \\
\hline
\end{tabular}

Note: CFA countries include Burkina Faso, Cameroon, the Central African Republic, Chad, the Republic of Congo, Côte d'Ivoire, Gabon, Mali, Niger, Senegal and Togo; non-CFA countries include Botswana, the Gambia, Ghana, Kenya, Malawi, Mauritius, Nigeria, Sierra Leone, Tanzania, Uganda and Zimbabwe; Latin America is defined as Argentina, Bolivia, Brazil, Chile, Colombia, Ecuador, Mexico, Uruguay and Venezuela; Asia is defined as Hong Kong, Indonesia, Korea, Malaysia, the Philippines, Singapore, Taiwan and Thailand.

1 Weighted averages, calculated using 1990 GDP and PPP exchanges rates. 2 The real effective exchange rates, expressed in terms of relative consumer prices, and the terms of trade (export unit value/import unit value) are shown as levels at the beginning of each period (1985 = 100). For CFA and non-CFA countries, the real effective exchange rates are real bilateral exchange rates vis-à-vis the US dollar; for Latin America and Asia, vis-à-vis main trading partners. An increase indicates an appreciation. ${ }^{3}$ Excluding Chad and Mali. ${ }^{4}$ Excluding Mali. ${ }^{5}$ Excluding Uganda. ${ }^{6}$ Excluding Chile. ${ }^{7}$ Excluding Hong Kong and Taiwan. ${ }^{8}$ Excluding Taiwan. 


\subsection{Fiscal indicators}

The tight monetary policy pursued in the CFA zone to defend the fixed parity has not been supported by budgetary restraint. Indeed, as can be seen from Table 2, the government budget deficit in terms of GDP has always been sizable, and since 1985, has exceeded that of the non-CFA countries by a significant margin. This difference in budgetary performance can be traced to the revenue side, where the CFA franc countries saw their public sector revenue relative to GDP declining (Nashashibi and Bazzoni (1993)). ${ }^{4}$ This underscores the difficulties faced by CFA franc countries in consolidating their budgetary positions in periods of stagnant or declining output. Furthermore, the continued rise of the wage bill in relation to GDP crowded out important infrastructure investment projects. By contrast, the non-CFA countries succeeded keeping the growth of the government wage bill below that of other expenditure, partly by reducing the size of their civil services and partly because nominal wage adjustments lagged behind rapid increases in consumer prices.

\subsection{Investment and saving}

Given the importance of investment in supporting economic growth and that of saving in co-determining the current external balance, it is useful to review the evolution of investment and saving over time. Both have experienced strong fluctuations in relation to GDP, but with a marked tendency towards declining gross saving over the period 1984-93.5 It was particularly pronounced in the CFA area, where the worsening in the terms of trade (see below) and the loss of external competitiveness contributed to a sharp swing in the government saving position from positive saving, equivalent to some 3\% of GDP in 1986, to dissaving of 3\% by 1993 (see Hadjimichael et al. (1994)); furthermore, the decline in real per capita income weakened the propensity to save in the business and household sectors. In the non-CFA countries the fall in the saving ratio was less spectacular, but the subsequent rebound in 1994-95 was also less impressive than in the CFA zone.

The drop in the aggregate investment/GDP ratio of the CFA franc countries to only $14 \%$ in 1993 was even more dramatic than that in the saving ratio. This slump in investment is disappointing when seen in the light of the "guaranteed convertibility" of the CFA franc vis-à-vis the French franc. In theory, this should have created a stable and favourable investment climate for both domestic and foreign investors. One of the factors behind the weakness was the severe budget constraint, which, as noted above, resulted in major cuts in government investment spending. The

4 These differences in revenue growth were mostly due to tax revenue. For the CFA franc countries, the terms-of-trade deterioration associated with the real exchange rate appreciation triggered a decrease in export income and led to a lower volume of recorded imports as a result of the slowdown in the economy. As the tax base was heavily dependent on imports, total tax revenue declined. In the non-CFA countries, the decline in the terms of trade was "offset" by a depreciation of the real effective exchange rate. The import/GDP ratio increased, thereby "protecting" the tax base.

5 It should be noted that in highly indebted countries there are important differences between domestic and national saving owing to large net interest payments. Hence, in Table 2, the current account deficit tends to exceed the difference between domestic saving and investment. 
rebound of the investment ratio observed in 1994 may reflect the high import content of projects valued at the new exchange rate and higher project aid disbursements.

Table 2

Selected economic indicators in Africa ${ }^{1}$

Annual averages, as a percentage of $\mathrm{GDP}^{2}$

\begin{tabular}{|c|c|c|c|}
\hline & 1981-85 & 1986-93 & 1994-95 \\
\hline \multicolumn{4}{|l|}{ CFA countries } \\
\hline M2 & 20.6 & 22.9 & 19.3 \\
\hline Government budget balance & $-3.3^{3}$ & -6.9 & -5.3 \\
\hline Gross domestic investment & 20.9 & 16.2 & $17.8^{4}$ \\
\hline Gross domestic saving & 16.3 & 13.2 & $16.0^{4}$ \\
\hline Current account balance & -6.2 & -6.6 & -3.3 \\
\hline External debt & 59 & 81 & 144 \\
\hline External debt / Exports & 226 & 381 & 477 \\
\hline \multicolumn{4}{|l|}{ Non-CFA countries } \\
\hline M2 & 20.2 & 18.3 & 22.5 \\
\hline Government budget balance & $-3.4^{5}$ & -4.3 & -4.2 \\
\hline Gross domestic investment & $16.1^{5}$ & 17.9 & $18.6^{4}$ \\
\hline Gross domestic saving & $14.5^{5}$ & 12.9 & $13.0^{4}$ \\
\hline Current account balance & -3.3 & -3.3 & $-5.0^{4}$ \\
\hline External debt & 40 & 57 & 90 \\
\hline External debt / Exports & 211 & 317 & 360 \\
\hline \multicolumn{4}{|l|}{ Nigeria } \\
\hline M2 & 29.9 & 22.2 & 21.9 \\
\hline Government budget balance & -5.3 & -9.2 & -5.7 \\
\hline Gross domestic investment & 13.7 & 9.9 & $9.2^{4}$ \\
\hline Gross domestic saving & 15.8 & 24.3 & $15.3^{4}$ \\
\hline Current account balance & -3.8 & 3.3 & -4.8 \\
\hline External debt & 14 & 53 & 101 \\
\hline External debt / Exports & 64 & 430 & 357 \\
\hline
\end{tabular}

${ }^{1}$ Weighted averages, calculated using 1990 GDP and PPP exchanges rates. 2 The external debt and the external debt/export ratio are for the beginning of each period. ${ }^{3}$ Excluding Chad. ${ }^{4}$ 1994. ${ }^{5}$ Excluding Uganda.

The weak investment performance in the CFA area contrasts with the simultaneous buoyancy of investment in non-CFA countries, even in a period of high inflation and related weak credibility of the authorities' commitment to a stable macroeconomic environment. 


\subsection{External sector developments}

External developments for the two areas display common as well as different features (see Chart 2 and Table 2). Common to both country groups have been the rising external debt ratios with respect to both GDP and exports, with the debt position of the CFA franc countries deteriorating at a faster pace than that of the non-CFA countries.

Chart 2

\section{Current account balance, output gap and real bilateral exchange rates}

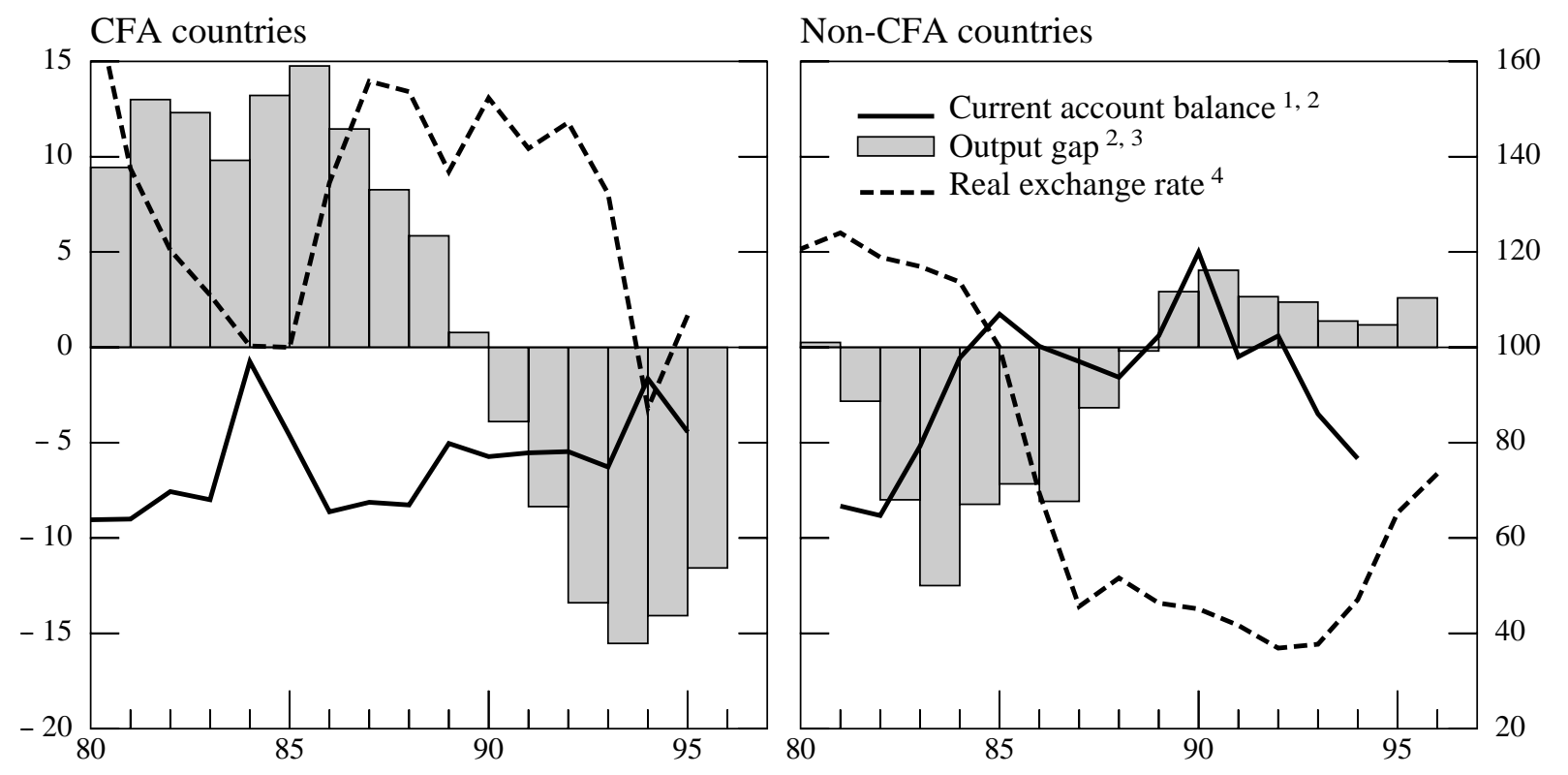

Note: The countries (as specified in Chart 1) are aggregated using 1990 GDP and PPP exchange rates.

${ }^{1}$ As a percentage of GDP. ${ }^{2}$ Left-hand scale. ${ }^{3}$ Annual percentage changes. ${ }^{4}$ Vis-à-vis the US dollar; an increase indicates an appreciation of the domestic currencies. $1985=100$; right-hand scale.

By contrast, current account balances and real exchange rates have shown quite different behaviour between the two groups. The current account balance of the CFA franc countries was always in deficit, though with some tendency to improve after 1986, while that of the non-CFA countries moved into temporary surplus on three occasions but tended to deteriorate during the first half of the 1990s. Real exchange rate movements were erratic for the CFA franc countries, while the non-CFA countries saw their real exchange rates decline until the strong recovery observed since 1993.

For the CFA franc countries, changes in the pressure of demand, as measured by the output gap, had little or no influence on the current account position, contrary to "normal" textbook behaviour. This can be attributed to the development of exports, which were very buoyant prior to 1986, but were rather weak in the late 1980s and early 1990s when the pressure on resources was easing. The non-CFA countries conformed to normal behaviour as the output gap tended to move in the opposite direction to the external balance. This scissors movement was reinforced by a marked 
weakening of economic activity in industrial countries, which constitute the main destination for the area's primary commodity exports, as well as a collapse of economic activity in the economies in transition.

While during the period prior to 1985 the terms of trade moved in opposite directions in the two areas (see Chart 3), all Sub-Saharan countries subsequently suffered a sustained period of sharply worsening terms of trade, with the CFA franc countries being the harder hit.

Chart 3

\section{Terms of trade and real bilateral exchange rates}

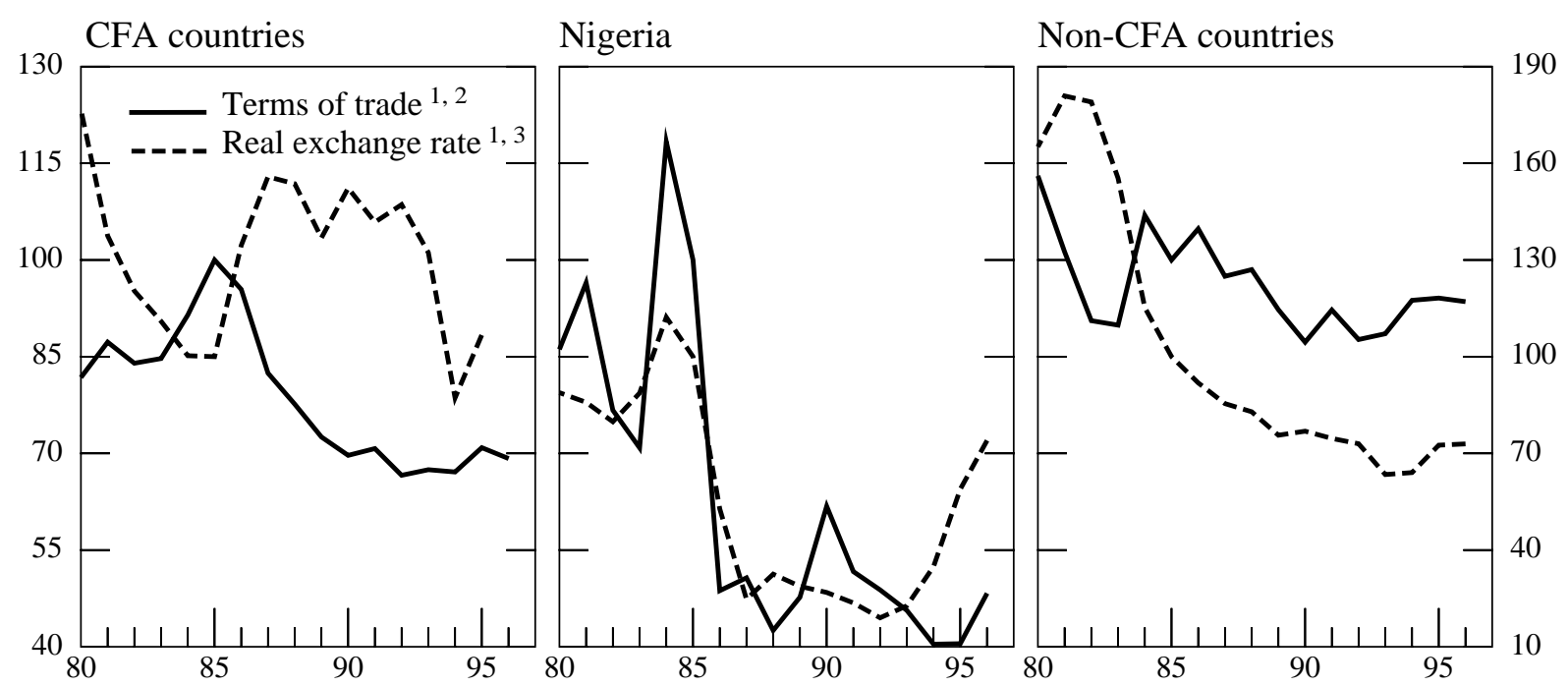

Note: The countries (as specified in Chart 1, except for non-CFA countries, which excludes Nigeria) are aggregated using 1990 GDP and PPP exchange rates.

${ }^{1} 1985=100 . \quad{ }^{2}$ Left-hand scale. $\quad{ }^{3}$ Vis-à-vis the US dollar; an increase indicates an appreciation of the domestic currencies. Right-hand scale.

The domestic policy response to these losses in terms of nominal exchange rate adjustments was significantly different in the two regions. In theory, a permanent deterioration of the terms of trade should lead to a depreciation of the equilibrium real effective exchange rate. ${ }^{6}$ In practice, a real depreciation can take place in two ways depending on the exchange rate regime: a nominal depreciation which closes the "gap" between the actual and the equilibrium real exchange rate; or a fixed nominal rate combined with price and wage increases below those of trading partners.

Countries in the non-CFA area took the first route by moving away from pegged currencies and the resulting adjustments moderated the adverse impact on domestic producer prices of the weakening of world commodity prices - an overvalued exchange rate can indeed be considered as an implicit tax on exports - and also contributed to reducing the current account deficit. But, given the

6 A more formal analysis of the terms-of-trade effects can be found in Kahn and Ostry (1991). 
high dependence of Sub-Saharan countries on imports, the benefits of devaluation were weakened by the induced inflationary pressure. Overall, the non-CFA countries thus counteracted the impact on output growth of the terms-of-trade losses but "paid" for this with higher inflation.

The CFA franc countries chose the second route, which requires output to be kept below potential for an extended period in order to bring about a disinflationary process. This enabled them to limit the loss in external competitiveness by maintaining inflation at low levels. Nonetheless, they had to face a nominal and a real appreciation, primarily because of the firming of the French franc against the US dollar in the second half of the 1980s. ${ }^{7}$ As a consequence, the CFA franc countries saw their external gaps widen sharply, and to meet the financing need they had to rely entirely on internal adjustment measures and external assistance.

\section{Recent research on inflation and output in developing countries}

The impact of exchange rate regimes and exchange rate movements on inflation and growth has been discussed in many empirical studies of developing countries. But the findings of these studies differ and cannot be generalised. As to inflation, there is a broad consensus about the role of monetary growth either as the main driving force behind inflation or, otherwise, as a necessary element in accommodating inflation triggered by other factors. ${ }^{8}$ However, the impact of nominal exchange rate flexibility on inflation is more ambiguous. All empirical researchs confirm that depreciations of the nominal exchange rate are correlated with temporary increases in consumer prices. ${ }^{9}$ Moreover, Gosh et al. (1995) found evidence that the average rate of inflation was lower in countries with pegged exchange rates than in countries with more flexible rates. ${ }^{10}$ Aghevli et al. (1991) obtained similar results but note that many countries with pegged exchange rate regimes have experienced high rates of inflation as a result of inappropriate fiscal policies. Conversely, many of the countries with more flexible arrangements have obtained lower rates of inflation by adopting prudent fiscal policies. Similarly, Siklos (1996) concluded that countries with fixed exchange rate regimes

7 Devarajan and Rodrik (1991) also observed that, despite low inflation rates, the CFA franc countries were unable to adjust their economies to the large terms-of-trade shocks of the mid-1980s, and that the inability to use nominal devaluation as an instrument led to a real appreciation. The resulting deterioration in external competitiveness triggered a contraction in economic activity.

8 Greene (1989) gives an overview of relevant inflation paradigms.

9 It should, however, be noted that the general positive correlation between exchange rate depreciation and temporary increases in consumer prices gives no information about the direction of causality. A devaluation of the nominal exchange rate can thus lead to inflation through the direct or indirect effect of higher import prices. On the other hand, if the inflation rate of a particular country is higher than that of its main trading partners, a devaluation to maintain external competitiveness would, sooner or later, be induced.

10 The anti-inflationary benefit of a fixed exchange rate regime was derived both from lower money supply growth, which can be interpreted as a discipline effect, and higher money demand growth, a credibility effect. 
often experienced higher, rather than lower, average inflation rates because the regimes were not credible. ${ }^{11,12}$ Overall, as Quirk (1994) observed, differences between the various exchange rate regimes have narrowed, once adjustments in the case of fixed exchange rate regimes are taken into account. Furthermore, he pointed out that the stability of the exchange rate and thus of inflation has become a "by-product" of other policy choices. As already mentioned, many developing countries have been subjected, since the mid-1980s, to frequent terms-of-trade shocks and have therefore adopted more flexible exchange rate regimes in order to avoid a deterioration in external competitiveness. But as Kamin (1997) showed in the case of Mexico, the real depreciation of the peso had a strong inflationary impact. Similar results were obtained by Calvo et al. (1994), who found that in the cases of Brazil, Chile and Colombia undervalued real exchange rates were associated with higher consumer price inflation. Overall, it thus appears that not only changes in the nominal exchange rate but also the level of the real effective exchange rate are correlated with the rate of inflation.

Views on the linkages between exchange rate changes and economic growth are even more controversial. According to the conventional theory, a devaluation generally leads to an expansion in output, because it enhances production in the export and import-competing sectors (see, for example, Dornbusch (1980)). ${ }^{13}$ In addition, by stimulating growth in the tradable sector, a low exchange rate might place a country on a development path with greater potential for sustained growth. More generally, a flexible nominal exchange rate facilitates adjustment and helps to restore output growth after negative shocks. In contrast to their findings with respect to inflation, Gosh et al. (1995) found no evidence that output growth varies significantly across countries with different exchange rate regimes. ${ }^{14}$ This is consistent with Hoffmaister et al. (1997), who noted that over the period 1971-93 output fluctuations were very similar across different country samples. By contrast, Agénor (1991) found that an anticipated depreciation of the real exchange rate had a negative effect on economic activity, while an unanticipated depreciation led to an increase in output. Furthermore, the notion of contractionary devaluations has in recent years found some empirical support. ${ }^{15}$ As pointed out by Krugman and Taylor (1978), devaluations lead to immediate increases in prices of export and import goods relative to home goods. Profits in the tradable sectors may therefore improve. If nominal

11 Siklos recognises, however, that the positive inflation performance associated with flexible exchange rate regimes could be spurious, owing to a potential confusion between cause and effect. Countries that are already in a declining inflationary process may opt for more flexible exchange rate systems.

12 A formal approach to account for the credibility criteria can be found in Calvo and Végh (1991).

13 Dornbusch gives an overview of relevant models.

14 The factors driving growth were, however, quite different in size and importance, with investment and trade growth in particular significantly higher under fixed than under flexible regimes. On the other hand, residual productivity growth, i.e. the effect of the speed of sectoral adjustment to shocks, was greater under flexible exchange rate regimes. This factor was even sufficient to offset the growth effects of higher trade and investment growth under pegged rates.

15 See Agénor (1991) for a survey of the literature on contractionary devaluations. 
wages lag the price increase and the marginal propensity to save from profits is higher than that from salaries, ex ante national saving increases, leading to a reduction in aggregate demand and thus a contraction in output, at least in the short term. An additional contractionary effect caused by devaluations might emerge through the channel of the external debt, often denominated in foreign currencies. Indeed, devaluations increase the resources used for servicing the external debt and thus crowd out investment. With respect to the impact of exchange rate changes on output, one finding of the study by Kamin and Rogers (1997) on Mexico was that depreciation shocks (real or nominal, levels or changes) may trigger a decline in economic activity. ${ }^{16}$ Edwards (1989) obtained similar results: holding government spending, the terms of trade and measures of money growth constant, devaluations tended to reduce output. By contrast, Ghura and Hadjimichael (1996) noted that growth was negatively correlated with real effective exchange rate changes. ${ }^{17}$ Furthermore, countries experienced higher growth rates if their actual real effective exchange rates converged more rapidly towards the respective equilibrium levels. The empirical evidence on the effects of exchange rate changes on economic activity would thus seem rather inconclusive.

\section{Analytical framework and estimation approach}

\subsection{The inflation equation}

In order to quantify the relationship between the rate of inflation and the level of the real effective exchange rate in the two Sub-Saharan African regions, the analytical framework developed in Kamin (1997) for various non-African regions of the world has been used in this study. The model is of particular interest for the two African regions since it includes the level of the real exchange rate, which differed between them (see Chart 1), in the inflation equation (see equation (3) below). The model can therefore be used to test the possible dilemma faced by policy-makers wishing to achieve both price stability and external competitiveness. The analytical framework rests on three major assumptions. First, domestic prices in country $C$ respond to a discrepancy between the actual and the equilibrium real exchange rate according to a partial adjustment equation: ${ }^{18}$

$\Delta \log P_{d, t}=\lambda\left(\log \left(P_{d} / P_{f}\right)_{t-1}-\log \left(\bar{P}_{d} / \bar{P}_{f}\right)_{t-1}\right)$

where: $P_{d}$ is the price of the domestic good determined by equilibrium in the market for domestic goods, $P_{f}$ is the price of the foreign good determined by the exchange rate $E$ (local currency

\footnotetext{
16 Hoffmaister and Végh (1996) arrived at similar results for Uruguay.

17 An increase in the real effective exchange rate indicates an appreciation.

18 Country $C$ is a small open economy producing, consuming and exporting a domestic good (d) and importing and consuming a foreign good $(f)$.
} 
per unit of foreign currency) and the exogenous foreign currency price of foreign goods $P_{f}^{*}$ and $\Delta$ a difference operator.

Second, the equilibrium real exchange rate is a log linear function of the market condition for the good produced in country $C$ such that the equilibrium exchange rate is consistent with market equilibrium:

$\log \left(\bar{P}_{d} / \bar{P}_{f}\right)=\theta-\varepsilon \log (A / \tilde{Y})$

where: $A$ is domestic absorption, $\tilde{Y}$ is potential output in country $C$ and $\theta$ a constant term.

By inserting (2) into (1), the rate of change in domestic prices is thus a function of disequilibrium in the domestic market (as in the usual Phillips curve) as well as of a possible discrepancy between the actual and the equilibrium real exchange rate. The third assumption in Kamin's model is that changes in domestic absorption and the nominal exchange rate depend on expectations and monetary and fiscal policies in country $C$.

In order to make the price adjustment equation operational and compatible with the data available, three additional but less crucial assumptions are made:

(i) As domestic goods price inflation is not available, consumer price inflation - a weighted average of domestic and foreign goods price inflation - is used:

$\Delta \log P=\alpha \Delta \log P_{d}+(1-\alpha) \Delta \log P_{f}$

(ii) Actual real GDP $(Y)$ is used as a proxy for absorption $(A)$. Thus, the ratio of absorption to potential GDP is proxied by the output gap. As already mentioned, the multilateral real effective exchange rate, $\log$ of $R E R$, is a function of the $\log$ of the ratio of domestic to foreign goods prices:

$\operatorname{RER}=\left(P /\left(P^{*} E\right)\right)=\left(\left(P_{d}{ }^{\alpha} P_{f}^{1-\alpha}\right) / P_{f}\right)=\left(P_{d} / P_{f}\right)^{\alpha}$

(iii) Finally, as persistence in price adjustment or the rate of inflation might occur, a lagged dependent variable is also included.

With these additional assumptions, the estimation equation can be written as follows:

$\Delta \log P_{t}=-\alpha \lambda \theta+\lambda \log R E R_{t-1}+\alpha \varepsilon \lambda(\log Y-\log \bar{Y})_{t-1}+(1-\alpha) \Delta \log P_{t}^{*}+(1-\alpha) \Delta \log E_{t}$ $+\beta \Delta \log P_{t-1}$

As seen above, a policy of real exchange rate targeting is undertaken either to keep the level of the real exchange rate constant in the face of domestic or external shocks, thus avoiding losses in competitiveness, or to aim at a different, usually a more depreciated, level in order to enhance competitiveness. Hence, a depreciation of the real exchange rate relative to the equilibrium level, by 
raising foreign goods prices relative to home goods prices, shifts domestic demand towards home goods, thereby triggering a rise in home goods prices until the real exchange rate reaches its equilibrium level. ${ }^{19}$

The estimation equation can be considered as a more general, open-economy version of the conventional output-gap-based Phillips curve. Indeed, when $\lambda=0$ and $\alpha=1$ and lagged inflation is a proxy for expected inflation, the equation becomes the Phillips curve for a closed economy. It differs from the conventional model in that the incorporation of lagged foreign price and nominal exchange rate changes better capture the dynamics of inflation.

However, before confronting (3) with the data, some comments are necessary. First, the assumption that prices in country $\mathrm{C}$ respond with the same speed and to the same extent to changes in the nominal exchange rate and foreign prices may be too restrictive (for instance, domestic producers or importers may regard exchange rate changes as merely temporary while changes in foreign prices are seen as permanent). Hence, the parameter constraint on $\Delta \log P_{t}^{*}$ and $\Delta \log E_{t}$ may not be satisfied. Second, it is quite possible that a dual causal relationship between the rate of domestic inflation and changes in the nominal exchange rate exists, implying that the coefficient on $\Delta \log E_{t}$ is subject to a positive bias. Finally, given the uncertainty about the existence and determination of the equilibrium exchange rate, the second assumption in the Kamin model may not hold. For instance, if the equilibrium exchange rate has to satisfy a PPP condition rather than equilibrium in the domestic market, the output gap may play only a minor role as a determinant of inflation.

\subsection{The output equation}

The equation below, based on Kamin and Klau (1997), represents an error-correction model for output, which incorporates the contractionary hypothesis discussed above. It is assumed that output is cointegrated with potential output, so that the output gap expresses the error in the cointegrating vector. Changes in output, $\log Y$, are induced by non-zero levels of the output gap, $\log Y-\log \bar{Y}$, as reflected in the magnitude of the coefficient $\alpha_{4}$, with positive output gaps having a depressing effect on output growth (i.e. $\alpha_{4}$ should be negative). Additional dynamics in the reaction of output growth to shocks are captured by the coefficient on lagged output growth $\alpha_{3}$. The impact of the real effective exchange rate, $\log R E R$, on output is measured in two ways. First, changes in the real effective exchange rate may have a temporary impact which it dissipates over time, so that, in steady state, the level of output is unchanged. This short-term effect will be reflected in $\alpha_{1}$. Second, a possible longer-term effect of the real effective exchange rate on output is captured by the coefficient $\alpha_{2}$, for which the a priori sign is ambiguous.

$\Delta \log Y_{t}=\gamma+\alpha_{1} \Delta \log R E R_{t}+\alpha_{2} \log R E R_{t-1}+\alpha_{3} \Delta \log Y_{t-1}+\alpha_{4}(\log Y-\log \bar{Y})_{t-1}$

19 The consequence of a policy of targeting a more depreciated level can also be found in a theoretical framework in Calvo et al. (1994). 


\section{Panel regression estimates}

\subsection{Data and methodology}

Most of the data on economic developments in the 22 Sub-Saharan countries were taken from the IMF International Financial Statistics, Balance of Payments and World Economic Outlook database and from the World Development Indicators of the World Bank. In the case of Sub-Saharan countries, these data must be treated with a high degree of caution. For example, official price data frequently report prices in the capital city only and may be distorted by official prices subject to controls. Concerning the nominal exchange rates, Agénor et al. (1989) note the role of parallel foreign exchange markets in current transactions. However, differences in "official" black market rates were smaller after the exchange rate adjustments and the liberalisation of the exchange rate regimes in the second half of the 1980s. ${ }^{20}$ Since real effective exchange rates were not available for all countries, they were calculated on the basis of real bilateral rates against the US dollar, which allowed all 22 countries to be included. This methodology can be justified by the fact that Sub-Saharan countries essentially export commodities for which world prices are determined in US dollars. As GDP deflators were also lacking for a number of countries, real GDP was expressed as an index calculated on the basis of GDP growth rates; from this, real per capita GDP growth rates were derived. The underdeveloped nature of the financial markets explains why interest rates were not used as control variables in this study.

The variables used are:

$P=$ consumer prices, yearly average;

$P^{*}=$ US consumer prices, yearly average;

$E R=$ nominal exchange rate (local currency per US dollar), yearly average;

$R E R=$ bilateral real exchange rate vis-à-vis the US dollar, yearly average. An increase indicates an appreciation;

$Y=$ real GDP;

$\log Y-\log \bar{Y}=\log$ ratio of actual to potential real GDP, with the latter estimated by applying the HP filter to actual real GDP;

$T O T=$ terms of trade (export unit value/import unit value);

$B U D G D P=$ budget balance as a percentage of GDP.

\subsection{Linkages between consumer price inflation and the exchange rate}

The equations were estimated using pooled annual data for the period 1980-96 for the two Sub-Saharan regions allowing for fixed effects. Thus, the intercept is estimated separately for each

20 Dhonte et al. (1994) found that for many countries the spread between the official and parallel market rates was significantly lower in mid-1994 than it was at the end of 1990. Burundi and Nigeria were the main exceptions, where the spreads widened. 
individual country. The slope coefficients are constrained to be the same across countries in each panel country group. For each region, ordinary least squares (OLS) and, to control for endogeneity of contemporaneous changes in the nominal exchange rate, instrumental variable (IV) estimations were used. The rate of US consumer price inflation is exogenous to all the countries in the sample and the lagged values of consumer price inflation, the level of the real exchange rate and the output gap are predetermined. The results for equation (3) are shown in Table 3.

As regards the first OLS estimation for each region (columns 1 and 6), except for the output gap, all coefficients are statistically significant or nearly so and of the expected sign.

Turning to the output gap, it is generally expected that inflation and the pressure on resources are closely correlated (e.g. Coe and McDermott (1997)). The inclusion of the output gap as an explanatory variable should also control for shocks to productivity, as these latter could induce changes in potential GDP and thus in the output gap. The statistical insignificance of the coefficient on the output gap can be explained either by the method of calculation of the level of real GDP, linking GDP growth rates, or of the output trend, using a Hodrick-Prescott filter, or more likely by the fact that the required structures for a market economy in Sub-Saharan countries were and/or are still not in place. ${ }^{21}$ Indeed, in most Sub-Saharan countries, many prices are state-controlled. As already discussed above, it may also be that the real exchange rate does not depend on the output gap.

With respect to the lagged dependent variable, the coefficient for the CFA franc countries is much lower than that for the non-CFA countries. A fairly low degree of persistence in inflation, even allowing for the fact that annual data are being used, was also found for Asia, Latin America and the industrialised countries in Kamin (1997). ${ }^{22}$ A general interpretation of the coefficient on the lagged dependent variable is therefore difficult. For instance, it could be argued that the CFA franc coefficient reflects the credibility of the monetary policy followed by these countries and that the high coefficient for the non-CFA countries shows that the monetary policy pursued by many of them were not credible. However, this argumentation could not be applied to Kamin's results as Asia and Latin America had similar coefficients. Conversely, it is possible that factors signalling future price increases would be more likely to trigger an inflationary response in a high-inflation environment, as in the non-CFA countries, and generate a higher coefficient on lagged price changes. However, in this case, one would expect a higher coefficient for Latin America than for Asia.

As expected, increases in foreign consumer price inflation - in this case US price inflation - push up domestic inflation. For both regions, the high coefficient suggests that changes in domestic consumer prices are highly sensitive to changes in import prices.

21 Coe and McDermott (1997) used a non-parametric method to estimate trend output. This method has the advantage of allowing the data to determine the degree of smoothing, whereas the Hodrick-Prescott filter requires the user to specify an arbitrary smoothing parameter. Applying their gap model to several Asian countries, they found that the nonparametric method performed better than estimates based on a Hodrick-Prescott filter.

22 For Asia and Latin America, the coefficient was around 0.20, for the industrialised countries around 0.35. 
Nominal exchange rate depreciations also boost price inflation. The coefficient on the nominal exchange rate is similar for both groups. A possible factor explaining the responsiveness of inflation to changes in the nominal exchange rate and to changes in foreign prices is the degree of openness of an economy. In principle, open economies should be more sensitive to exchange rate movements, as changes in import costs would have an impact on the supply of and/or demand for domestic goods. ${ }^{23}$ Here again, the similarities in terms of economic structure, and therefore in the sensitivity to changes in import prices through the channel of nominal devaluations might be an explanation for the similar coefficients.

Table 3

\section{Fixed effects panel regressions}

Dependent variable: $\Delta \log P$

\begin{tabular}{|c|c|c|c|c|c|c|c|c|c|}
\hline & \multicolumn{5}{|c|}{ CFA countries } & \multicolumn{4}{|c|}{ Non-CFA countries } \\
\hline & OLS & OLS & OLS & OLS & IV & OLS & OLS & OLS & IV \\
\hline$\Delta \log P_{-1}$ & $\begin{array}{c}0.18 \\
(3.17)\end{array}$ & $\begin{array}{c}0.21 \\
(3.49)\end{array}$ & $\begin{array}{c}0.17 \\
(2.93)\end{array}$ & $\begin{array}{c}0.33 \\
(5.12)\end{array}$ & $\begin{array}{c}0.18 \\
(3.08)\end{array}$ & $\begin{array}{c}0.42 \\
(6.71)\end{array}$ & $\begin{array}{c}0.42 \\
(6.68)\end{array}$ & $\begin{array}{c}0.42 \\
(6.72)\end{array}$ & $\begin{array}{c}0.39 \\
(6.04)\end{array}$ \\
\hline$\Delta \log P^{*}$ & $\begin{array}{c}1.04 \\
(4.40)\end{array}$ & $\begin{array}{c}0.99 \\
(3.41)\end{array}$ & $\begin{array}{c}1.12 \\
(4.59)\end{array}$ & $\begin{array}{c}1.17 \\
(5.45)\end{array}$ & $\begin{array}{c}0.51 \\
(1.45)\end{array}$ & $\begin{array}{c}0.86 \\
(1.93)\end{array}$ & $\begin{array}{c}0.17 \\
(0.32)\end{array}$ & $\begin{array}{c}0.81 \\
(1.82)\end{array}$ & $\begin{array}{c}0.78 \\
(1.15)\end{array}$ \\
\hline$\Delta \log E R$ & $\begin{array}{c}0.32 \\
(15.70)\end{array}$ & $\begin{array}{c}0.16 \\
(1.47)\end{array}$ & $\begin{array}{c}0.33 \\
(15.36)\end{array}$ & $\begin{array}{c}0.13 \\
(3.93)\end{array}$ & $\begin{array}{c}0.36 \\
(10.94)\end{array}$ & $\begin{array}{c}0.33 \\
(7.31)\end{array}$ & $\begin{array}{c}0.19 \\
(2.35)\end{array}$ & $\begin{array}{c}0.33 \\
(7.22)\end{array}$ & $\begin{array}{c}0.38 \\
(6.58)\end{array}$ \\
\hline $\log R E R_{-1}$ & $\begin{array}{l}-0.16 \\
(-5.58)\end{array}$ & $\begin{array}{c}-0.15 \\
(-4.95)\end{array}$ & $\begin{array}{c}-0.17 \\
(-5.67)\end{array}$ & $\begin{array}{c}-0.12 \\
(-3.96)\end{array}$ & $\begin{array}{c}-0.16 \\
(-5.06)\end{array}$ & $\begin{array}{c}-0.05 \\
(-2.02)\end{array}$ & $\begin{array}{c}-0.05 \\
(-1.75)\end{array}$ & $\begin{array}{c}-0.05 \\
(-2.01)\end{array}$ & $\begin{array}{c}-0.06 \\
(-2.07)\end{array}$ \\
\hline$(\log Y-\log \bar{Y})_{-1}$ & $\begin{array}{c}-0.01 \\
(-0.37)\end{array}$ & $\begin{array}{c}0.01 \\
(0.19)\end{array}$ & $\begin{array}{c}-0.03 \\
(-0.76)\end{array}$ & $\begin{array}{c}0.02 \\
(0.55)\end{array}$ & $\begin{array}{c}-0.01 \\
(-0.12)\end{array}$ & $\begin{array}{c}0.05 \\
(0.35)\end{array}$ & $\begin{array}{c}0.01 \\
(0.09)\end{array}$ & $\begin{array}{c}0.04 \\
(0.31)\end{array}$ & $\begin{array}{c}0.02 \\
(0.13)\end{array}$ \\
\hline Dumtot* $* \Delta \log E R$ & & $\begin{array}{c}0.18 \\
(1.71)\end{array}$ & & & & & $\begin{array}{c}0.20 \\
(2.16)\end{array}$ & & \\
\hline${\text { Dumtot } * \log R E R_{-1}}$ & & $\begin{array}{l}-0.00 \\
(0.59)\end{array}$ & & & & & $\begin{array}{c}-0.02 \\
(-2.15)\end{array}$ & & \\
\hline$\Delta \log T O T$ & & & $\begin{array}{c}-0.08 \\
(-2.21)\end{array}$ & & & & & $\begin{array}{c}-0.07 \\
(-1.28)\end{array}$ & \\
\hline Dumdev $* \Delta \log E R$ & & & & $\begin{array}{c}0.30 \\
(5.64)\end{array}$ & & & & & \\
\hline Dumdev $* \log R E R_{-1}$ & & & & $\begin{array}{c}-0.00 \\
(-0.03)\end{array}$ & & & & & \\
\hline
\end{tabular}

Note: $\mathrm{t}$-statistics in parentheses. $P=$ average annual consumer price inflation; $P^{*}=\mathrm{US}$ average annual consumer price inflation; $E R=$ nominal exchange rate (an increase indicates a depreciation); $R E R=$ real exchange rate (an increase indicates an appreciation); $(\log Y-\log \bar{Y})=\log ($ real GDP $)-\log ($ potential real GDP); Dumtot $=$ time dummy $(=0$ prior to $1985 ;=1$ thereafter); Dumdev = time dummy ( $=0$ prior to $1994 ;=1$ thereafter).

Instruments for IV: $\Delta \log P_{-1}, \Delta \log P^{*}, \Delta \log E R_{-1}, \log R E R_{-1},(\log Y-\log \bar{Y})_{-1}$, lagged level of terms of trade and lagged government budget balance as a percentage of GDP.

23 Increases in import prices can have an impact on inflationary pressures, either directly or through an increase in the price of domestically produced manufactures which either compete with imports or require imported intermediate goods. 
With regard to the real effective exchange rate, an appreciated level is associated with a lower rate of inflation. The higher coefficient on the real exchange rate for the CFA franc countries suggests that by maintaining a highly appreciated real exchange rate these countries have been able to keep inflation at a lower level than the non-CFA countries. It is interesting to compare these results with those obtained by Kamin (1997). He found that the responsiveness of inflation to the real exchange rate level is higher in Latin America than either in Asia or in industrial countries. It appears that the impact of the exchange rate level might be non-linear, as countries such as the Asian and nonCFA countries that have been able to maintain the competitiveness of their exchange rates obtain a relatively low coefficient. It should, however, be noted that in the case of Latin America the inability to combine competitiveness with price stability has resulted in or was triggered by a certain degree of instability in macroeconomic policy; in the CFA franc countries, the general unsustainable situation eventually led to a devaluation of the currency. The results underline the dilemma faced by policymakers wishing to achieve both price stability and external competitiveness.

The use of IV estimation instead of OLS makes little difference to the results (cf. columns 1 and 5 and 6 and 9 of Table 3) except that the coefficient on foreign inflation declines. As a result, the IV estimates come close to satisfying the theoretical parameter constraint on nominal exchange rate movements and foreign price inflation (see equation (3)). This implies that once the possible endogeneity of contemporaneous nominal exchange rate movements is controlled for, foreign price inflation and nominal exchange rate changes have the same impact on inflation.

As noted above, Sub-Saharan countries were exposed to terms-of-trade shocks in the second half of the 1980s. Normally, a deterioration in the terms of trade can be, sooner or later, expected to lead to a depreciation of the equilibrium real exchange rate. Therefore, the terms of trade should interact with both the nominal and the real exchange rate level. Columns 2 and 7 of Table 3 present a first approach to seeing whether such shocks have had a bearing on consumer price inflation. Both explanatory variables in the basic model were interacted with a "terms-of-trade time" dummy variable $(=0$ for the period prior to $1985 ;=1$ thereafter). For the CFA franc countries, most coefficients remain largely unchanged. However, for the nominal exchange rate, the coefficient for the period prior to 1985 is only half as large as for the period thereafter (0.16 against 0.34$)$. As seen previously, the CFA franc countries pursued a credible contractionary monetary policy in the period 1986-94 and experienced an appreciation of their currency against the US dollar (in line with the appreciation of the French franc against the US dollar) in the second half of the 1980s. The combination of these two events - appreciation and contractionary monetary policy - led to a low level of inflation, an outcome that is partly captured by the higher coefficient on the nominal exchange rate change. It is also interesting to note that in the course of the first half of the 1980s the nominal and real exchange rates depreciated. According to the estimation results, the negative coefficient on the real exchange rate for the first half of the 1980s would have produced more inflation. But during that period inflation fell. Therefore the impact on inflation triggered by the real exchange rate was more than offset by either an improvement in the terms of trade - lower import prices - or a credible and 
restrictive monetary policy (see Chart 3). As to the real effective exchange rate, it appears that, for the CFA franc countries, the terms-of-trade shock had no direct impact on the responsiveness of inflation to the level of the real exchange rate. For the non-CFA countries, the adoption of more flexible exchange rate regimes in the second half of the 1980s affected the import price channel of inflation. Together with the expansionary monetary policy conducted by the non-CFA countries, this might explain the higher responsiveness of inflation to nominal exchange rate changes (in general, devaluations) after the terms-of-trade shocks (0.19 against 0.39$).{ }^{24}$

The inclusion of the terms of trade as a separate explanatory variable in the inflation equation does not affect the impact of the level of the real exchange rate on inflation (see columns 3 and 8). However, as expected, a worsening of the terms of trade via higher import prices pushes up domestic inflation. For the non-CFA countries, the statistical insignificance of the coefficient might be explained by the fact that these countries usually responded to changes in the terms of trade by adjusting their nominal exchange rates.

In order to see whether the devaluation of the CFA franc in January 1994 had a direct impact on inflation, both explanatory variables were similarly interacted with a "devaluation time" dummy variable ( $=0$ for the period prior to $1994 ;=1$ thereafter). It appears that the nominal devaluation had a significant short-run impact on consumer prices but that there was no long-term effect, as the coefficient on the lagged level of the real exchange rate did not change (see column 4). However, in evaluating this result the extremely short observation period should be borne in mind.

\subsection{Linkages between output growth and the exchange rate}

Table 4 presents the results for the output equation (4). For each region, the equation was estimated using both OLS and, to control for the endogeneity of the contemporaneous change in the real exchange rate, IV estimations.

The coefficient on the output gap is, as expected, negative (see columns 1 and 5). ${ }^{25}$ The coefficient on lagged output growth for the CFA franc countries is significant and of the expected sign, while for the non-CFA countries it is statistically insignificant but also of the expected sign. This might suggest that shocks to growth tend to be absorbed immediately, for example through exchange rate adjustments. Another explanation might be that weather conditions have a marked influence on agricultural output in African countries and that weather-related supply shocks - for example, a drought - affect the harvest of the same year only. This could also explain the relatively small coefficient on lagged output growth for the CFA franc countries, compared with the values obtained by Kamin and Klau (1997) for non-African countries. ${ }^{26}$

\footnotetext{
24 Annual expansion in broad money of $34 \%$ (see Table 2).

25 This result is predetermined by the method by which the HP filter calculates trend GDP.

26 For Latin America the coefficient was 0.4, for Asia 0.5 and for the industrialised countries 0.6.
} 
The coefficient on the lagged level of the real exchange rate is negative in both regions. This, in line with conventional textbook analysis, suggests that in the long run real appreciations have a negative impact on economic activity.

Table 4

\section{Fixed effects panel regressions}

Dependent variable: $\Delta \log Y$

\begin{tabular}{|c|c|c|c|c|c|c|c|c|c|}
\hline & \multicolumn{4}{|c|}{ CFA countries } & \multicolumn{5}{|c|}{ Non-CFA countries } \\
\hline & OLS & OLS & OLS & IV & OLS & OLS & OLS & OLS & IV \\
\hline$\Delta \log R E R$ & $\begin{array}{c}-0.05 \\
(-1.75)\end{array}$ & $\begin{array}{l}-0.06 \\
(-2.04)\end{array}$ & $\begin{array}{c}-0.07 \\
(-2.17)\end{array}$ & $\begin{array}{c}-0.06 \\
(-1.91)\end{array}$ & $\begin{array}{l}-0.00 \\
(-0.11)\end{array}$ & $\begin{array}{c}0.00 \\
(0.10)\end{array}$ & $\begin{array}{c}-0.00 \\
(-0.17)\end{array}$ & $\begin{array}{c}-0.01 \\
(-0.32)\end{array}$ & $\begin{array}{c}-0.03 \\
(-1.17)\end{array}$ \\
\hline $\log R E R_{-1}$ & $\begin{array}{c}-0.04 \\
(-1.92)\end{array}$ & $\begin{array}{c}-0.05 \\
(-2.27)\end{array}$ & $\begin{array}{c}-0.07 \\
(-2.74)\end{array}$ & $\begin{array}{c}-0.06 \\
(-2.38)\end{array}$ & $\begin{array}{c}-0.03 \\
(-3.45)\end{array}$ & $\begin{array}{c}-0.02 \\
(-2.80)\end{array}$ & $\begin{array}{c}-0.02 \\
(-3.23)\end{array}$ & $\begin{array}{c}-0.03 \\
(-3.85)\end{array}$ & $\begin{array}{c}-0.03 \\
(-3.67)\end{array}$ \\
\hline$\Delta \log Y_{-1}$ & $\begin{array}{c}0.23 \\
(2.78)\end{array}$ & $\begin{array}{c}0.17 \\
(2.17)\end{array}$ & $\begin{array}{c}0.13 \\
(1.59)\end{array}$ & $\begin{array}{c}0.17 \\
(2.16)\end{array}$ & $\begin{array}{c}0.08 \\
(1.02)\end{array}$ & $\begin{array}{c}0.08 \\
(0.99)\end{array}$ & $\begin{array}{c}0.10 \\
(1.25)\end{array}$ & $\begin{array}{c}0.10 \\
(1.26)\end{array}$ & $\begin{array}{c}0.01 \\
(0.07)\end{array}$ \\
\hline$(\log Y-\log \bar{Y})_{-1}$ & $\begin{array}{c}-0.16 \\
(-3.45)\end{array}$ & $\begin{array}{c}-0.21 \\
(-4.40)\end{array}$ & $\begin{array}{c}-0.21 \\
(-4.28)\end{array}$ & $\begin{array}{c}-0.20 \\
(-4.27)\end{array}$ & $\begin{array}{c}-0.12 \\
(-2.61)\end{array}$ & $\begin{array}{c}-0.13 \\
(-2.77)\end{array}$ & $\begin{array}{c}-0.09 \\
(-1.96)\end{array}$ & $\begin{array}{c}-0.08 \\
(-1.79)\end{array}$ & $\begin{array}{c}-0.05 \\
(-1.09)\end{array}$ \\
\hline $\log T O T_{-1}$ & & $\begin{array}{c}0.09 \\
(3.66)\end{array}$ & $\begin{array}{c}0.12 \\
(4.34)\end{array}$ & $\begin{array}{c}0.09 \\
(3.57)\end{array}$ & & $\begin{array}{c}-0.02 \\
(-1.51)\end{array}$ & $\begin{array}{l}-0.01 \\
(-1.17)\end{array}$ & & \\
\hline$\triangle B U D G D P$ & & & $\begin{array}{c}0.11 \\
(0.91)\end{array}$ & & & & $\begin{array}{c}0.17 \\
(2.96)\end{array}$ & $\begin{array}{c}0.18 \\
(3.17)\end{array}$ & $\begin{array}{c}0.25 \\
(2.48)\end{array}$ \\
\hline
\end{tabular}

Note: $\mathrm{t}$-statistics in parentheses. $Y=$ real GDP; $R E R=$ real exchange rate (an increase indicates appreciation); $(\log Y-\log \bar{Y})=\log ($ real GDP)-log (potential real GDP); TOT = terms of trade (export unit value/import unit value); $B U D G D P=$ budget balance as a percentage of GDP.

Instruments for IV: $\Delta \log Y_{-1}, \Delta \log R E R_{-1}, \log R E R_{-1},(\log Y-\log \bar{Y})_{-1}, \log T O T_{-1}$ for the CFA franc countries and $\triangle B U D G D P_{-1}$ for the non-CFA countries.

As to short-run effects of real exchange rate appreciations, they are found to be negative and statistically significant for the CFA franc countries. This is consistent with the observation in Section 1 that the real appreciation of the CFA franc against the US dollar between 1986 and 1994 coincided with a period of mostly falling output. For the non-CFA countries, the coefficient is also negative but small and statistically insignificant. Thus, the evidence does not support the hypothesis that devaluations might have a short-run contractionary impact on output.

Here again, it is interesting to compare the results with those obtained by Kamin and Klau (1997). While for Asia, Latin America and the industrialised countries there was no evidence of contractionary output effects of devaluations in the long run, they found such an impact in the short run. Differences in the empirical results might be explained by the underdeveloped nature of the financial markets in African countries. Indeed, devaluations in Sub-Saharan Africa were certainly not associated with heavy capital flight and banking system failures. All in all, it thus appears that the empirical evidence on the short-run effects of adjustments in the real exchange rate on growth remains inconclusive. 
Since the estimated links between the real exchange rate and real output might reflect a spurious correlation with third factors, additional explanatory indicators were considered as control instruments. First, the terms of trade were included in order to capture external shocks (see columns 2 and 6). For the CFA franc countries, an improvement in the terms of trade leads to an increase in economic activity. By contrast, for the non-CFA countries, the coefficient is statistically insignificant. It should be borne in mind that in the non-CFA countries terms-of-trade shocks were counteracted by exchange rate adjustments, so that exchange rate and terms-of-trade changes were largely offsetting, with the result that both coefficients are insignificant. As for the other coefficients, the introduction of the control variable does not have any systematic influence.

A second indicator, fiscal policy, measured as the change in the ratio of the government budget balance to GDP, was added to capture internal shocks. ${ }^{27}$ A loosening of fiscal policy might depreciate the real exchange rate and stimulate output, even if there are no direct linkages between the latter two variables. The estimation results (see columns 3 and 7) suggest that a rise in the budget balance - a tightening of fiscal policy - actually increases economic activity. It should, however, be pointed out that the empirical and theoretical literature on the direction of the effects of fiscal policy on economic activity is controversial (see, for example, Easterly and Rebelo (1993)). Moreover, budget data for the Sub-Saharan African countries are subject to large measurement errors. It is conceivable, however, that the improved fiscal performance of the non-CFA countries in the second half of the 1980s allowed the real exchange rate to converge towards its equilibrium path and that this policy mix by accelerating output growth, generated an endogenous improvement in the budget balance. Furthermore, the reduction in the budget deficit may have facilitated the private sector's access to bank credit - reflected in an increase in the investment ratio for the non-CFA countries thereby stimulating economic activity. Conversely, for the CFA franc countries, a major factor in the deteriorating fiscal performance was that the real exchange rate increasingly diverged from its equilibrium path, inducing a contraction in economic activity and a higher deficit. As for the terms-oftrade variable, the introduction of the second control instrument does not change the estimated short and long run effect of a devaluation on output.

All in all, external shocks seem to have had a greater impact on output in the CFA franc countries than in the non-CFA countries. On the other hand, domestic shocks were more relevant for the non-CFA countries. ${ }^{28}$ Overall, these findings suggest that a fixed exchange rate regime is helpful if disturbances are of domestic origin, whereas a more flexible exchange rate regime is preferable in the event of external shocks. Indeed, it appears that the CFA franc countries were particularly badly hit by external shocks, whereas domestic shocks were relatively smoothly absorbed. By contrast, in non-

\footnotetext{
27 As already mentioned, real short-term interest rates were not used as a measure of monetary policy, an account of the underdeveloped financial markets in Sub-Saharan countries and the lack of data. It should also be noted that since fiscal policy is measured by total budget changes, it is likely to contain a large cyclical, and thus endogenous, component.

28 Following a structural VAR approach, Hoffmaister et al. (1997) obtained similar results.
} 
CFA countries external shocks were cushioned through exchange rate adjustments, whereas domestic shocks have had a more lasting impact on the overall economy.

In order to control for possible feedbacks from output to the contemporaneous change in the real exchange rate and the budget balance for the non-CFA countries, the equations defined in column 2 and column 8 were also estimated with Two-Stage Least Squares. The estimation results (see columns 4 and 9) give no clear evidence of any endogeneity bias, even though the introduction of control variables increases the coefficient on the contemporaneous change of the real exchange rate for the non-CFA countries. This might suggest that the non-CFA countries were more sensitive to shocks that simultaneously enhance economic activity and induce devaluations. But the long-run effects of devaluation on output remain unchanged.

Overall, the empirical results show that no systematic difference due to the exchange rate regime emerges between the two regions. Under both regimes, devaluations stimulate economic activity in the long run. Nevertheless, the exchange rate regime matters to the extent that countries are hit by and have to absorb large supply shocks.

\section{Conclusion}

The empirical work presented above suggests the following conclusions. First, the results obtained for the two African regions confirm the empirical relationship between the level of the real exchange rate and the rate of consumer price inflation found for Asia, Latin America and selected industrialised countries. Thus, by maintaining a highly appreciated real exchange rate, the CFA franc countries kept inflation at a lower level than the non-CFA countries. This might reflect, on the one hand, the credible monetary policy pursued by the CFA franc countries at the cost of external competitiveness and, on the other hand, the ability of the non-CFA countries to maintain a competitive exchange rate, but at the cost of higher inflation and a less credible monetary policy. Policy-makers in inflation-prone countries would, thus, seem to be faced with a permanent dilemma: should policy priority be given to containing domestic inflation or to maintaining external competitiveness through currency depreciation; and in the event of external supply shocks should an external or an internal price level adjustment be the preferred option to restore equilibrium?

Second, this conflict between policy objectives tends to be exacerbated by the fact that in the two African regions devaluations have a positive impact on economic activity both in the short and in the long run. Thus, the results obtained for Africa contradict the evidence found by Kamin and Klau (1997). Further research into the factors underlying the differences between the regions is therefore called for, notably as to the role of financial markets and of cross-border short-term capital flows.

On the basis of these findings and considerations, the question of whether the pegging of the exchange rate of the CFA franc to the French franc has been to the advantage or the disadvantage 
of the CFA franc countries remains open. On the one hand, the long term benefits from low inflation and well-established credibility are important and outweigh the short-term costs of tight policy and financial discipline. On the other hand, it appears that the highly appreciated level of the exchange rate was one of the principal causes of the decline in output growth and per capita income in the late 1980s and early 1990s. In fact, the CFA franc countries did not have at their disposal the domestic policy instruments required to absorb the external terms-of-trade shocks and to cushion the adverse impact on competitiveness of the appreciation of the CFA franc against the US dollar. Eventually the resulting strains and imbalances led to the drastic devaluation of the exchange rate in early 1994. Against this background, the issue of "credibility versus flexibility" remains an important one in exchange rate policy decisions given that the nature and sources of the real shocks to which countries are exposed can be widely different. 


\section{Appendix 1}

The CFA (Communauté Financière Africaine) franc zone comprises a group of countries in Central and West Africa whose currencies have been linked to the French franc since 1948. The exchange rate for the CFA franc was set in October 1948 at a fixed parity of 0.5 CFA francs per French franc (owing to the introduction of the new French franc in 1968 the rate became 50 CFA francs per French franc). The CFA franc zone member countries had to devalue their currency in January 1994 by $50 \%$, the Comorian franc was devalued by $33 \%$.

CFA francs were issued in 1948 by the French "Caisse Centrale de la France d'Outremer" (CCFOM). Those institutional arrangements became inappropriate in the course of the 1950s and 1960s when member countries gained their independence. Thus, control of the currency issue was transferred in the early 1970s from the CCFOM to two regional central banks: the "Banque Centrale des États de l'Afrique de l'Ouest" (BCEAO) and the "Banque des États de l'Afrique Centrale" (BEAC). The 14 member countries of the CFA franc zone currently consist of three groups: the West African Economic and Monetary Union (WAEMU) - Benin, Burkina Faso, Côte d'Ivoire, Mali, Niger, Senegal and Togo - which was established in January 1994 and supplements the WAMU (West African Monetary Union), which was formed in November 1973; the Central African Economic and Monetary Community (CAEMC), established in March 1994, whose members are Cameroon, the Central African Republic, Chad, the Republic of Congo, Equatorial Guinea and Gabon; and finally, the Islamic Federal Republic of the Comoros, with the Central Bank of the Comoros. The main characteristics of the CFA franc zone are: convertibility of the CFA franc into French francs at a fixed

parity (currently 100 CFA francs per French franc and 75 Comoros francs per French franc); free capital mobility throughout the zone; furthermore, each central bank holds an operation account with the French Treasury into which it deposits $65 \%$ of its foreign exchange holdings; finally, the central banks are required by their statutes to maintain $20 \%$ foreign exchange coverage of their sight liabilities. 


\section{References}

Agénor, Pierre-Richard (1991): "Output, Devaluation and the Real Exchange Rate in Developing Countries". Weltwirtschaftliches Archiv, Vol. 127, pp. 18-41.

Aghevli, Bijan B., Mohsin S. Kahn and Peter J. Montiel (1991): "Exchange Rate Policy in Developing Countries: Some Analytical Issues". IMF Occasional Paper, No. 78.

Boughton, James M. (1991): "The CFA Franc Zone: Currency Union and Monetary Standard". IMF Working Paper, No. 91/133.

Calvo, Guillermo A. and Carlos A. Végh (1991): "Exchange-Rate-Based Stabilization under Imperfect Credibility". IMF Working Paper, No. 91/77.

Calvo, Guillermo A., Carmen M. Reinhart and Carlos A. Végh (1994): "Targeting the Real Exchange Rate: Theory and Evidence". IMF Working Paper, No. 94/22.

Canetti, Elie and Joshua Greene (1991): "Monetary Growth and Exchange Rate Depreciation as Causes of Inflation in African Countries: An empirical Analysis". IMF Working Paper, No. 91/67.

Chibber, Ajay and Stanley Fischer (1991): Economic Reform in Sub-Saharan Africa. A World Bank Symposium, Washington, D.C.

Clément, Jean A.P., Johannes Mueller, Stéphane Cossé and Jean Le Dem (1996): “Aftermath of the CFA Franc Devaluation". IMF Occasional Paper, No. 138.

Coe, David T. and John McDermott (1997): "Does the Gap Model Work for Asia?" IMF Staff Papers, Vol. 44, No. 1, pp. 59-79.

Devarajan, Shantayanan and Dani Rodrik (1991): "Do the Benefits of Fixed Exchange Rates Outweigh Their Costs? The Franc Zone in Africa". National Bureau of Economic Research, Working Papers, No. 3727.

Devarajan, Shantayanan and Jaime de Melo (1990): "Membership in the CFA Zone: Odyssean Journey or Trojan Horse?" The World Bank Working Papers, No. 482.

Dhonte, Pierre, Jean Clément, Mbuyamu Matungulu and Dawn Rehm (1993): "Economic Trends in Africa: The Economic Performance of Sub-Saharan African Countries". IMF Working Paper, No. 93/71.

Dhonte, Pierre, Daudi Ballali, Gilbert Terrier and Stéphane Cossé (1994): "Economic Trends in Africa: The Economic Performance of Sub-Saharan African Countries". IMF Working Paper, No. 94/109.

Dornbusch, Rudiger (1980): Open Economy Macroeconomics. New York: Basic Books.

Easterly, William and Sergio Rebelo (1993): "Fiscal Policy and Economic Growth: An Empirical Investigation”. Journal of Monetary Economics, Vol. 32, pp. 417-58.

Edwards, Sebastian (1989): "Real Exchange Rates, Devaluation and Adjustment". Cambridge, Massachusetts: MIT Press.

Ghura, Dhaneshwar and Michael T. Hadjimichael (1996): "Growth in Sub-Saharan Africa". IMF Staff Papers, Vol. 43, No. 3, pp. 605-34. 
Gosh, Atish R., Anne-Marie Gulde, Jonathan D. Ostry and Holger C. Wolf (1995): "Does the Nominal Exchange Rate Regime Matter?" IMF Working Paper, No. 95/121.

Greene, Joshua (1989): "Inflation in African Countries: General Issues and Effect on the Financial Sector". IMF Working Paper, No. 89/86.

Hadjimichael, Michael T., Dhaneshwar Ghura, Martin Mühleisen, Roger Nord and E. Murat Uçer (1994): "Effects of Macroeconomic Stability on Growth, Savings and Investment in SubSaharan Africa: An Empirical Investigation". IMF Working Paper, No. 94/98.

Hoffmaister, Alexander W. and Carlos A. Végh (1996): "Disinflation and the Recession-Now-VersusRecession-Later Hypothesis: Evidence from Uruguay". IMF Staff Papers, Vol. 43, No. 2, pp. 355-94.

Hoffmaister, Alexander W., Jorge E. Roldós and Peter Wickham (1997): "Macroeconomic Fluctuations in Sub-Saharan Africa”. IMF Working Paper, No. 97/82.

Kahn, Mohsin S. and Jonathan D. Ostry (1991): "Response of the Equilibrium Real Exchange Rate to Real Disturbances in Developing Countries". IMF Working Paper, No. 91/3.

Kamin, Steven B. (1997): "A multi-country comparison of the linkages between inflation and exchange rate competitiveness". BIS Working Papers, No. 45.

Kamin, Steven B. and Marc Klau (1997): "Some multy-country evidence on the effects of real exchange rates on output". BIS Working Papers, No. 48.

Kamin, Steven B. and John H. Rogers (1997): "Output and the Real Exchange Rate in Developing Countries: An Application to Mexico". International Finance Discussion Paper, No. 580, Board of Governors of the Federal Reserve System, Washington, D.C.

Krugman, Paul and Lance Taylor (1978): "Contractionary Effects of Devaluation". Journal of International Economics, Vol. 8, No. 3, pp. 445-57.

Nashashibi, Karim and Stefania Bazzoni (1993): "Alternative Exchange Rate Strategies and Fiscal Performance in Sub-Saharan Africa". IMF Working Paper, No. 93/68.

Quirk, Peter J. (1994): “Fixed or Floating Exchange Regimes: Does It Matter for Inflation?" IMF Working Paper, No. 94/134.

Siklos, Pierre L. (1996): "The Connection Between Exchange Rate Regimes and Credibility: An International Perspective". Exchange Rates and Monetary Policy, Proceedings of a conference held by the Bank of Canada, October 1996. 


\section{Recent BIS Working Papers}

No.

37

September 1996

38

October 1996

39

January 1997

40

March 1997

41

May 1997

42

June 1997

43

July 1997

44

July 1997

45

August 1997

46

September 1997

47

September 1997

48

September 1997

49

September 1997

50

November 1997

51

November 1997

52

January 1998
Title

Does the term structure predict recessions?

The international evidence

International agreements in the area of banking and

finance: accomplishments and outstanding issues

Banking system failures in developing and transition countries: diagnosis and prediction

Monetary policy operating procedures in industrial countries

The euro and European financial markets

Measuring monetary policy shocks in France, Germany and Italy: the role of the exchange rate

Exchange rate regimes and the expectations hypothesis of the term structure

Is there excess comovement of bond yields between countries?

A multi-country comparison of the linkages between inflation and exchange rate competitiveness

Global asset allocation in fixed income markets

Financial asset prices and monetary policy: theory and evidence

Some multi-country evidence on the effects of real exchange rates on output

Why does the yield curve predict economic activity?

Dissecting the evidence for Germany and the United States

The euro and the dollar

Forecast errors and financial developments

Inflation and disinflation in Iceland
Author

Henri Bernard

and Stefan Gerlach

William R. White

Patrick Honohan

Claudio E. V. Borio

Robert N. McCauley and William R. White

Frank Smets

Stefan Gerlach and Frank Smets

Gregory D. Sutton

Steven B. Kamin

Srichander

Ramaswamy

Frank Smets

Steven B. Kamin and Marc Klau

Frank Smets and Kostas Tsatsaronis

Robert N. McCauley

Palle S. Andersen

Palle S. Andersen and Már Guðmundsson 
ISSN 1020-0959 